JOURNAL OF PUBLIC HEALTH INOVATION, VOL. 02. NO. 01, DESEMBER 2021

DOI: $\underline{10.34305 / \mathrm{jphi} . \mathrm{v} 2 \mathrm{i} 1.380}$
Ciptaan disebarluaskan di bawah

Lisensi Creative Commons Atribusi-

NonKomersial-BerbagiSerupa 4.0

\title{
PERILAKU MEROKOK MAHASISWA UNIVERSITAS MUHAMMADIYAH JAKARTA PADA MASA PANDEMI COVID-19
}

\author{
Mustakim, Adinda Chairunnisa Hatta, Amira Mhuthia Adila, Alvira Damayanti, Deviana \\ Aninda Putri, Dewi Risqan Marfiah \\ Universitas Muhammadiyah Jakarta \\ mustakim@umj.ac.id
}

\begin{abstract}
Abstrak
Tembakau (Nicotiana Tobacco) adalah sejenis tanaman herbal yang mengandung zat alkolid nikotin. Pada salah satu universitas di Indonesia mahasiswa dengan perokok ringan yaitu sebanyak sebanyak $67,5 \%$ dan penyebab perilaku merokok tersebut adalah sebanyak 52,5\% mahasiswa memiliki pengetahuan rendah, sebanyak 37,5\% mahasiswa dipengaruhi oleh orang tua perokok, sebanyak 65\% mahasiswa dipengaruhi teman, sebanyak 43,8\% mahasiswa dipengaruhi stress dan sebanyak 46,3\% mahasiswa dipengaruhi iklan. Tujuan penelitian ini untuk mengetahui gambaran perilaku merokok mahasiswa Universitas Muhammadiyah Jakarta pada masa pandemi Covid-19.

Penelitian ini merupakan penelitian observasional tanpa memberikan intervensi terlebih dahulu kepada subjek penelitian. Analisis data yang digunakan untuk melihat gambaran perilaku adalah analisis univariat menggunakan aplikasi SPSS (Statistical Package for the Social Sciences) untuk melihat perbedaan proporsi mengenai perilaku merokok responden sebelum dan saat masa pandemi covid-19. Hasil uji statistik menunjukkan bahwa frekuensi perokok berdasarkan umur pertama kali merokok sebagian besar merokok pada usia lebih dari 16 tahun yaitu $(34,4 \%)$.

Berdasarkan perilaku merokok terkait frekuensi, jumlah batang setiap hari, tempat merokok dan lain - lainnya dilihat dari perbandingan terdapat perubahan antara sebelum adanya pandemi covid-19 dan sesudah adanya pandemi covid-19. Perubahan yang sangat terlihat terutama pada tempat merokok yang awalnya sebagian besar $(28,1 \%)$ di kampus menjadi di rumah sebanyak $(28,1 \%)$ saat adanya pandemi. Gambaran perilaku merokok mahasiswa Universitas Muhammadiyah Jakarta pada saat terjadinya pandemi seperti
\end{abstract}


JOURNAL OF PUBLIC HEALTH INOVATION, VOL. 02. NO. 01, DESEMBER 2021

DOI: $\underline{10.34305 / \mathrm{jphi} . \mathrm{v} 2 \mathrm{i} 1.380}$
Ciptaan disebarluaskan di bawah

Lisensi Creative Commons Atribusi-

NonKomersial-BerbagiSerupa 4.0

frekuensi merokok dalam sebulan, jumlah batang rokok yang dihisap dalam sehari, harga rokok terutama tempat merokok terdapat perbedaan dari sebelum terjadinya pandemi. Perbedaan yang paling terlihat pada tempat merokok, dimana tadinya banyak mahasiswa UMJ yang memilih merokok di kampus saat sebelum pandemi kemudian beralih menjadi merokok di rumah ketika pemerintah menerapkan sistem PSBB guna menekan angka terjadinya covid19. Tetapi bisa dilihat bahwa pandemi ini tidak mengubah proporsi dari merk rokok maupun harga rokok.

\section{Kata Kunci: Perilaku Merokok, Mahasiswa, Pandemi Covid-19}

\section{Pendahuluan}

Tembakau (Nicotiana tobacco) adalah sejenis tanaman herbal mengandung zat alkoloid nikotin, tanaman tersebut berasal dari Amerika Utara dan Amerika Selatan (Sejati, 2017).

Menurut Word Health Organization (WHO, 2020), tembakau membunuh di seluruh dunia tiap tahunnya lebih dari 8 juta orang. Kematian akibat dari penggunaan langsung tembakau mencapai lebih dari 7 juta orang dan kematian akibat dari paparan asap rokok orang lain sekitar 1,2 juta orang.

Faktor risiko yang diketahui dari merokok yaitu berbagai infeksi saluran pernafasan dan tingkat keparahan penyakit saluran pernapasan menjadi meningkat (Organization, 2020a).
Menurut Centers for Disease Control and Prevention (CDC, 2019), penyebab utama penyakit dan kematian di Amerika Serikat yang dapat dicegah yaitu merokok, lebih dari 480.000 kematian setiap tahun, atau sekitar 1 dari 5 kematian. Merokok pada tahun 2005 telah menurun dari 20,9\% (hampir 21 dari setiap 100 orang dewasa) menjadi $13,7 \%$ pada tahun 2018 (hampir 14 dari setiap 100 orang dewasa).

Indonesia merupakan negara urutan ketiga dengan konsumsi rokok terbesar di dunia setelah China dan India (sehatnegeriku.kemenkes.go.id).

Berdasarkan data dari Tobacco Atlasn (2012), di Indonesia jumlah batang rokok yang dikonsumsi cenderung meningkat dari 182 milyar batang pada 
JOURNAL OF PUBLIC HEALTH INOVATION, VOL. 02. NO. 01, DESEMBER 2021

DOI: $\underline{10.34305 / \mathrm{jphi} . \mathrm{v} 2 \mathrm{i} 1.380}$

tahun 2001 menjadi 260,8 milyar batang pada tahun 2009 (Kemenkes, n.d.)

Menurut Pusat Data dan Informasi Kementerian Kesehatan RI, prevalensi merokok secara nasional yaitu 29\%. Provinsi di Indonesia dengan prevalensi merokok tertinggi adalah Jawa Barat (32,7\%), sedangkan provinsi dengan prevalensi merokok terendah adalah Papua (21,9\%) (Kemenkes, n.d.).

Menurut Survei Sosial Ekonomi Nasional (Susenas) yang dilakukan pada bulan Maret 2019 oleh Badan Pusat Statistik (BPS), jumlah perokok di DKI Jakarta mencapai 26\% untuk usia 15 tahun ke atas dan rata-rata mereka menghabiskan 72 batang rokok per minggu atau 10,3 batang rokok per hari (Statistik, 2020).

Minarsih dalam Lubis dalam Kalemben (2016) menyatakan bahwa, berdasarkan data yang diperoleh dari Departemen Kesehatan Republik Indonesia jumlah wanita yang merokok di Indonesia mencapai $40,5 \%$ dari keseluruhan jumlah penduduk wanita yang ada. Peringkat pertama yaitu mahasiswa putri, kemudian disusul oleh pelajar. Berdasarkan penelitian tersebut, menurut Yunita dalam Kalemben (2016), diketahui bahwa mahasiswi yang
Ciptaan disebarluaskan di bawah

Lisensi Creative Commons Atribusi-

NonKomersial-BerbagiSerupa 4.0

Internasional.

pernah merokok di Universitas Hasanuddin sebesar 10,2\% (Kalemben, 2016).

Menurut Winda (2020) berdasarkan penelitiannya pada mahasiswa Fakultas Kedokteran Universitas Baiturrahmah, sebanyak $67,5 \%$ mahasiswa adalah perokok ringan, dan penyebab perilaku merokok tersebut adalah sebanyak 52,5\% mahasiswa memiliki pengetahuan rendah, sebanyak $37,5 \%$ mahasiswa dipengaruhi oleh orang tua perokok, sebanyak 65\% mahasiswa dipengaruhi teman, sebanyak 43,8\% mahasiswa dipengaruhi stress dan sebanyak 46,3\% mahasiswa dipengaruhi iklan (Intan et al., 2019).

Penyakit coronavirus 2019 (COVID-19) adalah infeksi saluran pernapasan yang disebabkan oleh coronavirus yang baru muncul yang pertama dikenali muncul di Wuhan, Tiongkok, pada bulan Desember 2019. Pengurutan genetika virus ini mengindikasikan bahwa virus ini berjenis betacoronavirus yang terkait erat dengan virus SARS (Organization, 2020b).

COVID-19 pertama dilaporkan di Indonesia pada tanggal 2 Maret 2020 berjumlah 2 kasus. Kemudian data 31 Maret 2020 menunjukkan kasus yang 
JOURNAL OF PUBLIC HEALTH INOVATION, VOL. 02. NO. 01, DESEMBER 2021

DOI: $\underline{10.34305 / \mathrm{jphi} . \mathrm{v} 2 \mathrm{i} 1.380}$

terkonfirmasi berjumlah 1.528 kasus dan 136 kasus kematian. Tingkat mortalitas COVID-19 di Indonesia sebesar 8,9\%, angka ini merupakan yang tertinggi di Asia Tenggara (Susilo et al., 2020). Saat ini ada sebanyak 65 negara terinfeksi virus corona. Menurut data WHO per tanggal 2 Maret 2020 jumlah penderita 90.308 terinfeksi Covid-19. Angka kematian diseluruh dunia mencapai 3.087 atau 2.3\% dengan angka kesembuhan 45.726 orang. Terbukti pasien konfrimasi Covid-19 di Indonesia berawal dari suatu acara di Jakarta dimana penderita kontak dengan seorang warga negara asing (WNA) asal jepang yang tinggal di Malaysia. Setelah pertemuan tersebut penderita mengeluhkan demam, batuk dan sesak napas (Yuliana, 2020).

Update status data sebaran COVID19 hari ini tanggal 21 juni 2020 ialah digambarkan pada tabel yang diunggah oleh website resmi COVID-19. Data Global di 216 negara terkonfirmasi 8.708 .008 positif COVID-19 dan meninggal 416.715. Di Indonesia data COVID-19 dengan kasus positif 45.891, sembuh 18.404 dan meninggal 2.465. Diakses pada tanggal 21 juni 2020 melalui https://covid19.go.id/
Ciptaan disebarluaskan di bawah

Lisensi Creative Commons Atribusi-

NonKomersial-BerbagiSerupa 4.0 Internasional

\section{Metode}

Penelitian ini merupakan penelitian observasional tanpa memberikan intervensi terlebih dahulu kepada subjek penelitian. Data yang diperoleh merupakan data primer yang diambil langsung oleh peneliti melalui pengisian kuesioner. Analisis data yang digunakan untuk melihat gambaran perilaku adalah analisis univariat menggunakan aplikasi SPSS (Statistical Package for the Social Sciences) untuk melihat perbedaan proporsi mengenai perilaku merokok responden sebelum dan saat masa pandemi covid-19.

Lokasi penelitian di Universitas Muhammadiyah Jakarta baik di Kampus A maupun Kampus B. Populasi penelitian adalah mahasiwa Universitas Muhammadiyah Jakarta aktif dari berbagai fakultas angkatan 2016- 2019 yang merokok. Karena keterbatasan peneliti di masa pandemi maka pengambilan sampel dilakukan dengan metode accidental sampling, sehingga kami mendapatkan sampel sebanyak 32 mahasiswa perokok aktif sebelum adanya masa pandemi covid19.

Kuesioner yang digunakan untuk melihat gambaran perilaku baik dari masa 
JOURNAL OF PUBLIC HEALTH INOVATION, VOL. 02. NO. 01, DESEMBER 2021

DOI: $\underline{10.34305 / \mathrm{jphi} . \mathrm{v} 2 \mathrm{i} 1.380}$

sebelum pandemi maupun pandemi saat ini menggunakan referensi kuesioner dari Global Youth Tobacco Surveys. Variabel perilaku yang diteliti adalah frekuensi merokok, cara mendapatkan rokok, merk rokok, harga rokok, serta tempat merokok. Semua variabel perilaku akan diuraikan secara sebelum dan saat pandemi covid-19.
Ciptaan disebarluaskan di bawah

Lisensi Creative Commons Atribusi-

NonKomersial-BerbagiSerupa 4.0 Internasional.

\section{Hasil}

Berdasarkan Tabel 1 diketahui bahwa dari 32 responden mahasiswa yang menjadi sampel sebanyak $31 \quad(96,9 \%)$ mahasiswa berjenis kelamin laki- laki. Sementara itu hanya ada $1 \quad(3,1 \%)$ responden yang berjenis kelamin perempuan.

Tabel 1. Distribusi Karakteristik Responden Berdasarkan Jenis Kelamin

\begin{tabular}{lccc}
\hline \multirow{2}{*}{ Variabel } & \multirow{2}{*}{ Kategori } & $\mathbf{N}$ & Frekuensi \\
\cline { 3 - 4 } & & 31 & $\mathbf{\%}$ \\
\hline Jenis Kelamin & Laki-laki & 1 & 96,9 \\
& Perempuan & 3,1 \\
\hline
\end{tabular}

Berdasarkan Tabel 2 diketahui sebagian besar responden telah mematuhi PSBB yang dicanangkan oleh pemerintah guna menekan pertumbuhan covid-19 di Indonesia yaitu sebanyak $24(75,0 \%)$ dan sebagian kecil tidak menerapkan PSBB yaitu sebanyak $8(25,0 \%)$ responden.

Sementara dari sisi ekonomi, sebagian besar responden terdampak covid19 yaitu sebanyak $21(65,6 \%)$ dan sebagian kecil tidak terdampak covid-19 dari segi ekonomi yaitu sebanyak $11 \quad(34,4 \%)$ responden.

Untuk penerapan PHBS (Perilaku Hidup Bersih dan Sehat) pada masa pandemi sebagian besar responden menerapkan PHBS yaitu sebanyak 31 (96,9\%)dan sebagian kecil responden tidak menerapkan PBHS yaitu hanya $1(3,1 \%)$ responden.

Tabel 2. Distribusi Responden Berdasarkan Penerapan PSBB, Terdampak secara Ekonomi, dan Penerapan PHBS Saat Pandemi Covid-19

\begin{tabular}{lccc}
\hline \multirow{2}{*}{ Variabel } & \multirow{2}{*}{ Kategori } & $\mathbf{N}$ & Frekuensi \\
\cline { 3 - 4 } & & 31 & $\mathbf{\%}$ \\
\hline Jenis Kelamin & Laki-laki & 1 & 96,9 \\
& Perempuan & 3,1 \\
\hline
\end{tabular}


JOURNAL OF PUBLIC HEALTH INOVATION, VOL. 02. NO. 01, DESEMBER 2021

DOI: $\underline{10.34305 / \mathrm{jphi} . \mathrm{v} 2 \mathrm{i} 1.380}$

Berdasarkan Tabel 3 diketahui sebagian besar responden mulai mencoba merokok pada umur $\geq 16$ tahun yaitu sebanyak $11(34,4 \%)$ dan sebagian kecil
Ciptaan disebarluaskan di bawah Lisensi Creative Commons AtribusiNonKomersial-BerbagiSerupa 4.0 Internasional.

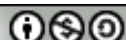

responden mulai mencoba rokok pada umur 8-9 tahun yaitu sebanyak $1 \quad(3,1 \%)$ responden.

Tabel 3. Distribusi Frekuensi Responden berdasarkan Umur Pertama Kali Merokok

\begin{tabular}{lccc}
\hline & Umur (tahun) & $\mathbf{N}$ & $\mathbf{\%}$ \\
\hline $8-9$ & 1 & 3,1 \\
$10-11$ & 6 & 18,8 \\
$12-13$ & 8 & 25,0 \\
$14-15$ & 6 & 18,8 \\
$\geq 16$ & 11 & 34,4 \\
\hline \multicolumn{2}{c}{} & $\mathbf{3 2}$ & $\mathbf{1 0 0 , 0}$ \\
\hline
\end{tabular}

Berdasarkan Tabel 4 diketahui sebelum terjadinya pandemi covid-19 sebagian besar responden merokok dalam sebulan selama 30 hari penuh yaitu sebanyak $18(56,3 \%)$ dan sebagian kecil responden merokok dengan frekuensi 3-5 hari dalam sebulan yaitu sebanyak $1(3,1 \%)$ responden. Sementara saat terjadinya pandemi terdapat pertambahan frekuensi perokok yang tidak merokok sama sekali selama sebulan yaitu dari 0 responden menjadi $4(12,5 \%)$ responden. Secara keseluruhan pandemi covid-19 mengubah frekuensi merokok responden dalam sebulan.

Tabel 4. Distribusi Frekuensi Responden Berdasarkan Frekuensi Merokok, Jumlah Batang, Dihsiap, Cara Mendapatkan Rokok, Merk Rokok, Harga dan Tempat Merokok

\begin{tabular}{lcccc}
\hline \multirow{2}{*}{ Frekuensi Merokok (hari) } & \multicolumn{2}{c}{ Sebelum Pandemi } & \multicolumn{2}{c}{ Saat Pandemi } \\
\cline { 2 - 5 } & $\mathbf{N}$ & $\mathbf{\%}$ & $\mathbf{N}$ & $\mathbf{\%}$ \\
\hline 0 & - & - & 4 & 3,1 \\
$1-2$ & 4 & 12,5 & 1 & 6,3 \\
$3-5$ & 1 & 3,1 & 2 & 9,4 \\
$6-9$ & 2 & 6,3 & 3 & 15,6 \\
$10-29$ & 7 & 21,9 & 5 & 53,1 \\
30 & 18 & 56,3 & 17 & \multicolumn{2}{c}{ Saat Pandemi } \\
\multicolumn{2}{c}{$\begin{array}{c}\text { Jumlah Batang Rokok } \\
\text { (Dalam Sehari) }\end{array}$} & \multicolumn{2}{c}{ Sebelum Pandemi }
\end{tabular}


JOURNAL OF PUBLIC HEALTH INOVATION, VOL. 02. NO. 01, DESEMBER 2021

DOI: $\underline{10.34305 / \text { jphi.v2i1.380 }}$
Ciptaan disebarluaskan di bawah

Lisensi Creative Commons Atribusi-

NonKomersial-BerbagiSerupa 4.0 Internasional.

\begin{tabular}{|c|c|c|c|c|}
\hline$<1$ & 4 & 12,5 & 2 & 6,3 \\
\hline 1 & 1 & 3,1 & 1 & 3,1 \\
\hline $2-5$ & 7 & 21,9 & 8 & 25,0 \\
\hline $6-10$ & 8 & 25,0 & 9 & 28,1 \\
\hline $11-20$ & 11 & 34,4 & 7 & 21,9 \\
\hline$>20$ & 1 & 3,1 & 1 & 3,1 \\
\hline Cara Mendapatkan Rokok & \multicolumn{2}{|c|}{ Sebelum Pandemi } & \multicolumn{2}{|c|}{ Saat Pandemi } \\
\hline Tidak merokok & - & - & 4 & 12,5 \\
\hline Beli di asongan & 1 & 3,1 & - & - \\
\hline Beli di toko/ warung & 27 & 84,4 & 27 & 84,4 \\
\hline Mencuri & 2 & 6,3 & - & - \\
\hline Dibelikan orang lain & 1 & 3,1 & 1 & 3,1 \\
\hline Lain-lain & 1 & 3,0 & - & - \\
\hline Merk Rokok & \multicolumn{2}{|c|}{ Sebelum Pandemi } & \multicolumn{2}{|c|}{ Saat Pandemi } \\
\hline Tidak merokok & - & - & 4 & 12,5 \\
\hline Gudang garam & 11 & 34,4 & 12 & 37,5 \\
\hline Jisamsu & 1 & 3,1 & 1 & 3,1 \\
\hline Malboro & 4 & 12,5 & 4 & 12,5 \\
\hline Sampurna & 10 & 31,3 & 8 & 25,0 \\
\hline Tidak punya merk tertentu & 1 & 3,1 & 2 & 6,3 \\
\hline Lain-lain & 5 & 15,6 & 1 & 3,1 \\
\hline Harga Rokok (Rp) & \multicolumn{2}{|c|}{ Sebelum Pandemi } & \multicolumn{2}{|c|}{ Saat Pandemi } \\
\hline Tidak merokok & - & - & 4 & 12,5 \\
\hline 1.500 & 10 & 31,3 & 8 & 25,0 \\
\hline 2.000 & 18 & 56,3 & 17 & 53,1 \\
\hline$\geq 3.500$ & 4 & 12,5 & 3 & 9,4 \\
\hline Tempat Merokok & \multicolumn{2}{|c|}{ Sebelum Pandemi } & \multicolumn{2}{|c|}{ Saat Pandemi } \\
\hline Tidak merokok & - & - & 4 & 12,5 \\
\hline Rumah & 4 & 12,5 & 9 & 28,1 \\
\hline Rumah teman & 4 & 12,5 & 5 & 15,6 \\
\hline Kampus & 9 & 28,1 & 2 & 6,3 \\
\hline Pertemuan-pertemuan & 5 & 15,6 & 2 & 6,3 \\
\hline $\begin{array}{l}\text { Tempat umum (pasar, mal, } \\
\text { sudut jalan) }\end{array}$ & 2 & 6,3 & 5 & 15,6 \\
\hline Lain-lain & 8 & 25,0 & 5 & 15,6 \\
\hline
\end{tabular}

Berdasarkan Tabel 4 diketahui sebelum pandemi covid-19 sebagian besar responden dalam seharinya menghabiskan 11-20 batang rokok yaitu sebanyak 11 $(34,4 \%)$ responden sementara hanya sebagian kecil responden yang menghabiskan satu batang dan lebih dari 20 batang dalam sehari yaitu masing- masing sebanyak $1(3,1 \%)$ responden. Sedangkan pada saat terjadinya pandemi covid-19 jumlah batang rokok yang dihisap dalam sehari mengalami perubahan. Jika sebelum pandemi mayoritas responeden merokok sebanyak 11-20 batang, namun setelah 
JOURNAL OF PUBLIC HEALTH INOVATION, VOL. 02. NO. 01, DESEMBER 2021

DOI: $\underline{10.34305 / \mathrm{jphi} . v 2 \mathrm{i} 1.380}$

adanya pandemi mayoritas responden merokok sebanyak 6-10 batang yaitu 9 $(28,1 \%)$.

\section{Pembahasan}

Hasil penelitian di atas menunjukan bahwa mahasiswa perokok mayoritas berasal dari kalangan laki- laki, hal ini sejalan dengan penelitian yang dilakukan Astuti tahun 2012 pada remaja di Bantul bahwa jenis kelamin laki- laki mendominasi perilaku merokok (Astuti, 2012). Laki- laki cenderung memiliki rasa ingin tahu yang tinggi, anggapan bahwa mereka tampak bebas dan dewasa saat mereka menyesuaikan diri dengan teman-teman sebayanya yang merokok, keinginan untuk terlihat gagah, dan sifat suka menentang (Febrijanto \& Fikriyah, 2012).

Fakultas dan angkatan yang mengisi kuesioner tidak kami jabarkan karena metode pengambilan sampel secara accidental sampling, dimana dalam penentuan sampel berdasarkan kebetulan, yaitu siapa saja yang secara kebetulan bertemu dengan penelitian dapat digunakan sebagai sampel sehingga hasilnya dapat bias (Ningrum et al., 2016).
Ciptaan disebarluaskan di bawah Lisensi Creative Commons AtribusiNonKomersial-BerbagiSerupa 4.0 Internasional
Berdasarkan tabel 4 distribusi umur pertama kali merokok sebagian besar responden merokok ketika usia mereka lebih dari atau sama dengan 16 tahun. Sementara menurut penelitian yang dilakukan oleh Komasari dan Helmi pada tahun 2000, sebagian besar responden pertama kalo merokok ketika mereka berada di justru bangku SLTP yang mana berusia sekitar 13-15 tahun (Komasari \& Helmi, 2000).

Penelitian deskritif lain yang dilakukan oleh Sulastri dkk, pada tahun 2018 juga memperkuat bahwa usia pertama kali mencoba rokok berada di rentang 14-15 tahun masih disekitar usia SMP/SLTP (Sulastri et al., 2018). Sedangkan berdasarkan Global Youth Tobacco Surveys: Indonesia reports pada tahun 2014 sebagian besar mulai mencoba rokok pada usia 12-13 tahun (WHO, 2015).

Berdasarkan table 4 distribusi frekuensi mengenai frekuensi merokok dalam sebulan baik sebelum maupun saat terjadinya pandemi saat ini, sebagian responden merokok selama tiga puluh hari penuh dalam sebulan. Hal ini sejalan dengan penelitan deskriptif yang dilakukan oleh Riska, dkk bahwa sebagian besar 
JOURNAL OF PUBLIC HEALTH INOVATION, VOL. 02. NO. 01, DESEMBER 2021

DOI: $\underline{10.34305 / \mathrm{jphi} . v 2 \mathrm{i} 1.380}$

perokok memiliki kebiasaan merokok selama satu bulan penuh setiap harinya dan bahkan mencapai persentase hingga 80,9\% (Rositaa et al., 2012).

Berdasarkan tabel 4 dapat dilihat sebelum terjadinya pandemi sebagian besar responden merokok sebanyak 11- 20 batang sehari sementara saat terjadinya pandemi saat ini sebagian besar perokok mengalami penurunan jumlah batang rokok menjadi 610 batang perhari. Kondisi sebelum pandemi terkait jumlah batang yang dihisap setiap harinya oleh perokok sejalan dengan penelitian deskriptif yang dilakukan oleh komasari, dkk pada tahun 2000 dimana sebagian besar responden memang merokok dari rentang 11 hingga 20 batang (Komasari \& Helmi, 2000). Namun pergeseran persentase mengenai jumlah rokok yang dihisap dalam satu hari pada Global Youth Tobacco Surveys dimana sebagian besar responden justru merokok kurang dari 1 batang per harinya mencapai 36,0 persen dengan CI 95\% (WHO, 2015). Setidaknya, masa pandemi memberi dampak terhadap penurunan jumlah batang rokok yang dihisap oleh perokok setiap harinya.

Berdasarkan pada tabel 4 menunjukan bahwa baik sebelum maupun
Ciptaan disebarluaskan di bawah

Lisensi Creative Commons Atribusi-

NonKomersial-BerbagiSerupa 4.0

Internasional.

saat terjadinya pandemi saat ini sebagian besar responden mendapatkan rokoknya dengan membeli di toko atau warung. Hal ini juga sejalan dengan hasik GYTS di Indonesia pada tahun 2014 dimana sebagian besar perokok memang mendapatkan akses untuk mendapatkan rokok dengan membelinya di warung atau toko (WHO, 2015). Pandemi tidak memberikan dampak terhadap bagaimana cara perokok mendapatkan rokoknya.

Berdasarkan tabel 4 dapat dilihat bahwa baik sebelum maupun saat pandemi, merk rokok Gudang garam menjadi favorit bagi responden yang kemudian disusul oleh sampoerna yang menjadi favorit kedua. Namun penelitian deskriptif lain yang dilakukan oleh Wattimury pada tahun 2013 menyatakan bahwa merk rokok yang menjadi favorit di kalangan perokok adalah merk sampoerna (Wattimury, 2013). Pandemi tidak memberi dampak pada merk rokok yang dibeli para responden.

Berdasarkan tabel 4 dapat dilihat terkait harga rokok baik sebelum maupun saat pandemi tetap saja sebagian besar responden mengeluarkan uang sebesar 2000 rupiah hanya saja mengalami penurunan persentase yang tidak begitu berselisih jauh. 
JOURNAL OF PUBLIC HEALTH INOVATION, VOL. 02. NO. 01, DESEMBER 2021

DOI: $\underline{10.34305 / \mathrm{jphi} . v 2 \mathrm{i} 1.380}$

Sementara menurut GYTS Indonesia tahun 2014, sebagian besar perokok mengeluarkan uang sebesar Rp10.000 hingga Rp15.000 per 20 batangnya. Harga ini setiap tahunnya mengalami pergeseran mengingat adanya faktor kenaikan cukai rokok setiap tahunnya.

Berdasarkan tabel 4 dapat dilihat terjadi perubahan yang sangat signifikan terkait tempat merokok yang dipilih responden yang bestatus mahasiswa dimana sebagian besarnya memilih kampus untuk dijadikan tempat mereka merokok sebelum adanya pandemi covid-19. Sementara saat adanya pandemi justru sebagian besar memilih rumah untuk dijadikan tempat merokok. Peraturan yang dicanangkan pemerintah terkait study from home guna menekan angka covid-19 mengubah perilaku perokok mahasiswa terkait tempat mereka merokok.

\section{Kesimpulan}

Gambaran perilaku merokok mahasiswa Universitas Muhammadiyah Jakarta pada saat terjadinya pandemi seperti frekuensi merokok dalam sebulan, jumlah batang rokok yang dihisap dalam sehari, harga rokok terutama tempat merokok
Ciptaan disebarluaskan di bawah

Lisensi Creative Commons Atribusi-

NonKomersial-BerbagiSerupa 4.0 Internasional

terdapat perbedaan dari sebelum terjadinya pandemi. Perbedaan yang paling terlihat ada pada tempat merokok, dimana tadinya banyak mahasiswa UMJ yang memilih merokok di kampus saat sebelum pandemi kemudian beralih menjadi merokok di rumah ketika pemerintah menerapkan sistem PSBB guna menekan angka terjadinya covid-19. Tetapi bisa dilihat bahwa pandemi ini tidak mengubah proporsi dari merk rokok maupun harga rokok.

\section{Saran}

Untuk mahasiswa, sebaiknya berusaha mengganti kebiasaan merokok dengan kebiasaan memakan makanan pengganti, seperti permen, coklat atau roti manis jika merasakan "mulut asam" jika tidak merokok.

Mencari kesibukan lain untuk mengalihkan pikiran, misalnya berjalanjalan menggunakan sepeda dan bermain bulu tangkis. Memberi sugesti pada diri sendiri dengan berpikir bahwa merokok menjadikan kita sebagai orang egois yang menyakiti diri sendiri dan orang lain. Mulai belajar mendengarkan orang yang kontra terhadap perilaku merokok. Kurangi asupan 
JOURNAL OF PUBLIC HEALTH INOVATION, VOL. 02. NO. 01, DESEMBER 2021

DOI: $\underline{10.34305 / \mathrm{jphi} . \mathrm{v} 2 \mathrm{i} 1.380}$

kafein seperti kopi, biasanya orang yang suka merokok identik dengan suka minum kopi, sehingga apabila mengurangi asupan kafein, otomatis konsumsi rokok akan berkurang. Hindari orang-orang yang merokok agar tidak tergoda untuk kembali merokok. Minta bantuan dokter apabila fisik mengalami kelainan yang menyebabkan tidak dapat berhenti merokok, misalnya tangan gemetar apabila tidak merokok, dan meminta bantuan dari psikiater untuk membantu menghilangkan kecanduan psikologis (perilaku merokoknya).

Untuk pemerintah, sebaiknya harga rokok ditetapkan setinggi-tingginya, seperti di beberapa negara tetangga yang maju, agar jumlah perokok berkurang secara masif. pulvinar

\section{Daftar Pustaka}

Astuti, K. (2012). Gambaran perilaku merokok pada remaja di kabupaten bantul. Insight, 10(1), 77-87.

CDC. (2019). Current Cigarette Smoking Among Adults in the United States.

Febrijanto, Y., \& Fikriyah, S. (2012). Factors That Influence the Smoking Behaviour of Male Students in Dormitories. Jurnal Penelitian STIKES Kediri, 5(1), 99-109-109.
Ciptaan disebarluaskan di bawah

Lisensi Creative Commons Atribusi-

NonKomersial-BerbagiSerupa 4.0

Intan, S. W., A, R., \& Fionaliza. (2019). Faktor -Faktor Yang Berhubungan Dengan Perilaku Merokok Pada Mahasiswa Fakultas Kedokteran Universitas Baiturrahmah Tahun 2015-2016. 45-51.

Kalemben, S. (2016). PERILAKU MEROKOK PADA MAHASISWI DI UNIVERSITAS HASANUDDIN KOTA MAKASSAR TAHUN 2016.

Kemenkes, P. (n.d.). Situasi Umum Konsumsi Tembakau Di Indonesia.

Komasari, D., \& Helmi, A. F. (2000). Faktor Faktor Penyebab Merokok Pada Remaja. Jurnal Psikologi, 27(1), $37-47$.

Ningrum, P., Aisyah, siti nur, \& Amelia, R. (2016). A CCIDENTAL SAMPLING AND. 1-7.

Organization, W. H. (2020a). Pernyataan WHO: Penggunaan tembakau dan COVID-19. May, 7-10.

Organization, W. H. (2020b). Tatalaksana klinis infeksi saluran pernapasan akut berat ( SARI ) suspek penyakit COVID-19. 4(March).

Rositaa, R., Dwi Linna Suswardanya, \& Abidin, Z. (2012). PENENTU KEBERHASILAN BERHENTI MEROKOK PADA MAHASISWA. 13(3), 304-313.

Sejati, D. (2017). RUPL.

Statistik, D. (2020). Perilaku perokok dki jakarta 2019. 3-6. 
Sulastri, S., Herman, D., \& Darwin, E. (2018). Keinginan Berhenti Merokok Pada Pelajar Perokok Berdasarkan Global Youth Tobacco Survey di SMK Negeri Kota Padang. Jurnal Kesehatan Andalas, $\quad 7(2), \quad 205$. https://doi.org/10.25077/jka.v7i2.803

Susilo, A., Rumende, C. M., Pitoyo, C. W., Santoso, W. D., Yulianti, M., Sinto, R., Singh, G., Nainggolan, L., Nelwan, E. J., Khie, L., Widhani, A., Wijaya, E., Wicaksana, B., Maksum, M., Annisa, F., Jasirwan, O. M., Yunihastuti, E., Penanganan, T., New, I., ... Cipto, R. (2020). Coronavirus Disease 2019: Tinjauan Literatur Terkini Coronavirus Disease 2019: Review of Current Literatures. Jurnal Penyakit Dalam Indonesia, 7(1), 4567.

Wattimury, A. A. (2013). Profil Pengetahuan Mahasiswa Fakultas Farmasi Universitas Surabaya
Ciptaan disebarluaskan di bawah

Lisensi Creative Commons Atribusi-

NonKomersial-BerbagiSerupa 4.0 Internasional.

Terhadap Bahaya Rokok. Jurnal Ilmiah Mahasiswa Universitas Surabaya, 2(1), 1-14.

WHO. (2015). Global Youth Tobacco Survey (GYTS): Indonesia report 2014. In Who-Searo (Nomor November).

https://doi.org/http://www.searo.who.i nt/tobacco/documents/ino gyts report _2014.pdf

WHO. (2020). Pernyataan WHO : Penggunaan tembakau dan COVID19. $7-10$.

Winda, SI. (2020). Faktor-faktor yang Berhubungan dengan Perilaku Merokok pada Mahasiswa Fakultas Kedokteran Universitas Baiturrahman. Padang : Universitas Baiturrahman.

Yuliana. (2020). Corona virus diseases (Covid -19); Sebuah tinjauan literatur. Wellness and healthy magazine, 2(1), 187-192. 